IRA-International Journal of Education \& Multidisciplinary Studies

ISSN 2455-2526; Vol.16, Issue 01 (Jan.-Mar. 2020)

Pg. no. 1-6.

Institute of Research Advances

https://research-advances.org/index.php/IJEMS
QUARTERLY

Institute of

Research

Advances

\title{
Comments and Analysis of the Main Schools of Modern Foreign Language Teaching Methods
}

Yin Hua

School of Foreign Language, Yangtze University, Jingzhou, Hubei, P. R. China

Type of Work: Peer-Reviewed

DOl: http://dx.doi.org/10.21013/jems.v16.n1.p1

\section{How to cite this paper:}

Hua, Y. (2020). Comments and Analysis of the Main Schools of Modern Foreign Language Teaching Methods. IRA International Journal of Education and Multidisciplinary Studies (ISSN 2455-2526), 16(1), 1-6. doi: http://dx.doi.org/10.21013/jems.v16.n1.p1

(C) Institute of Research Advances.

This work is licensed under a Creative Commons Attribution-Non Commercial 4.0 International License subject to a proper citation to the publication source of the work.

Disclaimer: The scholarly papers as reviewed and published by the Institute of Research Advances (IRA) are the views and opinions of their respective authors and are not the views or opinions of the IRA. The IRA disclaims of any harm or loss caused due to the published content to any party.

Institute of Research Advances is an institutional publisher member of Publishers International Linking Association Inc. (PILA-CrossRef), USA. The institute is an institutional signatory to the Budapest Open Access Initiative, Hungary advocating the open-access of scientific and scholarly knowledge. The Institute is a registered content provider under Open Access Initiative Protocol for Metadata Harvesting (OAI-PMH).

The journal is indexed \& included in WorldCat Discovery Service (USA), CrossRef Metadata Search (USA), WorldCat (USA), OCLC (USA), Open J-Gate (India), EZB (Germany) Scilit (Switzerland), Airiti (China), Bielefeld Academic Search Engine (BASE) of Bielefeld University, Germany, PKP Index of Simon Fraser University, Canada. 


\begin{abstract}
Modern foreign language teaching method is a diversified, multi-dimensional and multi-level system. It is helpful in improving the level of foreign language teaching in China and establishing a foreign language teaching system with Chinese characteristics to comment on and analyze some of the most influential foreign language teaching schools.
\end{abstract}

Keywords: foreign language teaching methods, foreign language teaching, the schools of teaching methods

Foreign language teaching method, an important part of foreign language teaching, is a science that studies the laws of foreign language teaching. Different schools of teaching methods have come into being under the guidance of linguistic, pedagogical, psychological and philosophical theories and with the continuous exploration and practice of many a diligent foreign language educator. Each school has its own characteristics, advantages, and disadvantages. They are worth analyzing and studying in order to summarize foreign language teaching experience, deepen the understanding of foreign language teaching rules and improve the level of foreign language teaching. On this basis, the system of foreign language teaching methods in China Can be explored. The following is a review and analysis of the major influential foreign language teaching schools in recent decades.

\title{
I. Audio-Lingual Method
}

Audio-Lingual Method/Aural-Oral Method is also called Structure Method, Linguistic Method, Pattern Method, Bloomfield's Method. Although the above names are different, the essence of them is the same. All are studies of foreign language teaching based on structuralist and behaviorist psychology when listening and speaking are put in the first place.

Since the 1940s, the demand for foreign language services has been increasing. Psychology, linguistics, and pedagogy have developed rapidly. With the progress of science and technology, foreign language teaching means and equipment have been further improved. New foreign language teaching methods have sprung up and flourished. Audio-Lingual Method is a newly emerging foreign language teaching method.

The emergence of the Audio-Lingual Method is a major event in the history of foreign language teaching. It promotes the development of foreign language teaching methods from both theoretical and practical aspects. In terms of theory, the theories of structuralist linguistics and behaviorist psychology are applied to foreign language teaching, laying a theoretical foundation for the Audio-Lingual Method, and thus foreign language teaching has been brought to a new historical stage. In practice, this method has been greatly improved compared with the traditional teaching method, which overcomes the tendency to attach more importance to reading, writing than listening and speaking.

The advantages of the Audio-Lingual Method: (1) The practicality of foreign language teaching as well as listening and speaking training is underlined so that students can speak and speak foreign languages fluently in the initial stage of learning a foreign language and within the limited range of materials. (2) A set of practice systems to cultivate language habits is established so that students can master language materials by themselves. (3) Students' mistakes should be avoided and corrected as soon as possible so as 
not to form wrong habits. (4) Contrastive methods are widely used to find out the difficulties in learning foreign languages on the basis of contrastive analysis of mother tongue and foreign languages, which are supposed to be solved pertinently in teaching practice.

The disadvantages of the Audio-Lingual Method: The structural form of language is overvalued while the content of language and social context are ignored. Although students can make many different sentences according to sentence patterns, they cannot use them properly in actual situations.

\section{Audio-Visual Method}

Audio-Visual Method is also called Situational Method, Saint Cloud Method. Come into being in the 1950s, Audio-Visual Method is a teaching method based on the Audio-Lingual Method. Its purpose is to cultivate students' listening, speaking, reading and writing skills.

From the aspect of the Audio-Visual Method, the process of foreign language teaching is the Stimulus-Response-Reinforcement process- the combination of image and sound stimulates the audiovisual senses before students make imitative responses and then intensive training is practiced repeatedly to form automatic habits. The combination of language and situation can create a process similar to mother-tongue learning without the mother tongue as a mediator. Students learn spoken language first and then written language in situations. [1]

The advantages of the audio-visual approach are as follows: (1) by teaching with modern technological equipment, the connection with the objective situation could be established featuring concrete images, easy memorization and lively classroom atmosphere so as to facilitate the exchange of ideas with foreign language directly. (2) The students' requirements for verbal communication could be met; the problems of traditional grammar or syntactical structure centralization could be solved, and the difficulty that without contextual contents, the natural verbal communication will fail could be overcome. (3) In daily life situations, the overall perception of the sound structure of a foreign language could be achieved and the pronunciation, vocabulary, and grammar could be acquired in the speech flow, all of which will be conducive to cultivate the ability of language usage flexibly. (4) The conditions for imagery thinking could be provided for students so as to promote their grasp of the language naturally and firmly; students' abilities and habits of correct pronunciation, intonation, rhythm, wording, and phrasing could be cultivated favorably.

The disadvantages of the audio-visual approach are as follows: it pays too much attention on the language forms and neglects the cultivation of communicative abilities; it overemphasizes the overall structure and ignores the analysis and interpretation of the different levels and units of language, which hinder students' understanding and application of the foreign language properly; The intuitive visual effects are overstressed and the assistant role of using native language to translate in teaching is neglected. 


\section{The Cognitive Approach}

The cognitive approach, also called the cognitive code approach, as a type of foreign language teaching approach or learning theory, emphasizes the students' intellectual role in foreign language teaching and the understanding of the language rules, and targets on the training of language application ability practically and comprehensively, thus, it is entitled the cognitive code theory as well.

In the $1960 \mathrm{~s}$, the development of science and technology soared and international competition has deepened into that field. The Audio-lingual approach and others could not keep pace with the new development trend, and the cognitive approach has been put forward under this circumstance. It objects to the theory claiming language as a structural mode, and is also against the repetitive mechanical exercise in teaching. It proposes that language is knowledge and is the rational cognitive activity in the human brain; it underlines the role of understanding in language teaching and claims to do creative communicative training based on the comprehension of the newly learned language materials. It is acceptable for the students to understand the foreign language materials with the help of the native language in teaching. The teaching process is divided into three stages: language comprehension, language application, and language ability cultivation.

The basic features of the cognitive approach are: (1) the training of the communicative ability is emphasized. Learning should be meaningful as the text learning should be according to the contextual situation and the audio-visual methods should be employed in contextualized and communicative teaching. (2) The spoken language and the written form are regarded complementarily, and ought to be developed at the same time. (3) It is underlined that practicing language should be based on the understanding of language knowledge and the rules, which should be taught with the deductive method. (4) Foreign language teaching needs to give priority to students' practice; the cultivation of the students' learning motivation should be paid attention to and the learning initiative should be fully activated with more practical activities to use a foreign language for the students to take part in.

The advantages of the cognitive approach are: it underlines the development of students' intellectual factors and stimulates students' active thinking to communicate creatively. It attaches great importance to arouse students' learning initiative and to cultivate students' scientific learning methods as well as to form good learning habits.

The disadvantages of the cognitive approach are: it overemphasizes the unfounded point of teaching foreign language on the basis of cognitive grammatical rules; it still requires further argumentation in terms of both theory and practice as a system of the foreign language teaching method.

\section{The Communicative Approach}

The communicative approach also called the functional approach or notional approach is a system of teaching method to foster communicative competence based on the functional items of language (such as to request, acceptance, rejection, etc.) as the key points. Its major principles include the establishment of the unit-credit system, the comprehensive application of the different elements in the speech communicative activities and the development of the communicative teaching process and of the language for special purposes. 
The communicative approach was originated in the western European countries, centered in the UK, in the early 1970s. Due to the rapid development of science and technology in society at that time, the increasingly frequent political, economic and cultural exchanges between countries and the urgent need for specialized foreign language talents in different areas, the communicative approach came into being. In order to maximize the teaching efficiency in the limited teaching time and to meet the various needs of the society for foreign languages, the communicative approach has emerged and has become one of the most influential foreign language teaching approaches in the world. Theoretically founded from sociolinguistics, psycholinguistics, and transformational generative grammar, its main teaching principle focuses on that the content determines the form, that is, what the students express and communicate, the language form and rules loading those ideas and thoughts should be taught.

The basic characteristics of the communicative approach are as follows: (1) The content of the teaching based on the language function is arranged according to the different needs of the learning objects. At present, we have to learn what we need to use in the future. In other words, we can first learn what we need urgently, not what we don't need, without asking the difficulty in language form. (2) The teaching process is communicative. To be specific, as the main part of the teaching activities, students are required to fully access and learn the language they are learning, especially authentic foreign languages. In addition, teachers should provide real situations and create a foreign language environment to make students learn and use the language actively and creatively. (3) It is normal for students to make language errors. In the process of learning a language, there must be an "interlanguage". When it gradually transits to perfect language, the errors will naturally disappear [2]. Therefore, teachers are not emphasized to correct the mistakes of students at any time, so as not to distract them as well as making them pay more attention to what they express. (4) When analyzing different structures that embody the same function, it may be advantageous to explain by grammar. Since the main premise of the communicative approach is to take the function as the outline and there may be multiple representations in each function or meaning, students with this concept will not mechanically equate two different language forms.

The advantages of the communicative approach are as follows: (1) Emphasizing the communication of foreign language teaching, it attaches importance to cultivating students' foreign language communication ability. (2) The approach is conducive to improving the quality of foreign language teaching since it encourages students to actively engage themselves in verbal communication activities without excessively aiming at correcting language errors.

The shortcomings of the communicative approach are as follows: (1) How to scientifically analyze and classify functional items needs further argumentation, for the scope of language functions is extremely wide. (2) Further discussion on how to correctly treat language errors and avoid the situation of "mistakes must be corrected" and "laissez-faire" is needed.

\section{Conclusion}

The four major influential foreign language teaching genres have been briefly evaluated and analyzed above. Reasonable reference to the teaching ideas of these genres is a way to promote the study and improve the quality of foreign language teaching in China. However, holding a correct attitude is a prerequisite for reasonable reference. And it should at least include the following aspects: 
First of all, we need to have an objective and comprehensive understanding of the basic viewpoints, teaching principles and teaching methods of various teaching systems. At the same time, we need to understand the background and production process of these teaching systems and their requirements for teaching conditions, or the scope of their application. In the second place, we have to analyze and generalize them and figure out the basic clues of their development and the intrinsic links between them.

Secondly, we should have a basic estimate and awareness of each pedagogy genre. No teaching genre is perfect. Each genre has its rationality and merits, but its problems and limitations still exist. Therefore, these teaching systems should be evaluated historically, objectively and comprehensively by the viewpoints and methods of historical materialism and dialectical materialism. That is to say, don't just accept a system because it works better in some ways.

Moreover, we should learn from each pedagogy genre in light of the actual situation, which consists of three aspects: one is the purpose of Chinese learning foreign languages; the other is our teaching conditions including the level of teachers, class size, teaching equipment, etc.; the third is the problems in our current teaching process. Besides, the teaching reform system should also be considered. It is important to note that we should take the part of each genre that fits our teaching practice and is effective, so as to make our teaching methods more comprehensive and effective.

Last but not least, no matter what kind of teaching method is adopted, attention should be paid to mobilizing the enthusiasm and initiative of students, cultivating their self-learning ability and innovative spirit, as well as encouraging and guiding them to actively participate in various language communication activities inside and outside the class. In teaching, we should be student-centered because their internal factors are the decisive factor in learning a foreign language.

In short, every teaching method has its own merits, and at the same time, they complement each other. So "taking the best of each other and using it for me" is the attitude we should take towards various teaching genres, and it is also the basic principle guiding our teaching practice. On the issue of establishing a foreign language teaching method system in China, the author will write another article to discuss.

\section{References:}

[1]. Cook, V. Second Language and Language Teaching[M]. London: Edward Arnold, 1991.

[2]. Richards, J. \& Rodgers, T. Approaches and Methods in Language Teaching[M]. New York: Cambridge University Press, 1986.

[3]. ZhangJianzhong.Foreign Language Pedagogy [M].Shanghai: Shanghai Foreign Language Education Press, 1997. 